\title{
FIRST COLOURED SPECIES OF THE GENUS THABENA STÅL (HEMIPTERA, FULGOROIDEA, ISSIDAE) FROM VIETNAM WITH GENERAL NOTES ON THE GENUS
}

\author{
Vladimir M. GNEZDilov \\ Zoological Institute of the Russian Academy of Sciences, Universitetskaya nab. 1 \\ Saint Petersburg 199034, Russia; E-mails: vmgnezdilov@mail.ru,vgnezdilov@zin.ru
}

\begin{abstract}
A new species of the genus Thabena Stål, 1866 is described from Dalat in Vietnam. Checklist of Thabena species is given. This is the first species of the genus with multicoloured metope which may be treated as a kind of mimicry to salticid spiders. Taxonomic position of the genus Thabena within the family Issidae and its close relationships to the tribe Parahiraciini is briefly discussed.
\end{abstract}

Key words: Issini, Parahiraciini, Caliscelidae, Chlamydopteryx, Lasonia, Redarator, Thabena, morphology, evolution, mimicry, taxonomy, new species.

\section{INTRODUCTION}

The genus Thabena Stål, 1866 (= Gelastyra Kirkaldy, 1904; = Gelastyrella Yang, 1994; = Borbonissus Bonfils, Attié et Reynaud, 2001) sensu GnezDilov (2009) belongs to the tribe Issini Spinola and it is endemic to Southeastern Asia with 14 species, including the species described below, known from China, Indonesia, Malaysia, Myanmar, Reunion I., Singapore, Taiwan, and Vietnam (GNezdilov 2009, 2013, GNezdilov et al. 2014a, CHAN et al. 2013, Bourgoin 2015). Two species are recorded from outside of native distribution - Thabena brunnifrons (Bonfils, Attié et Reynaud, 2001) was apparently imported from Asia to Réunion Island (France) and Rodrigues Island (Republic of Mauritius) in historic time (GNezDilov 2009, 2013), and Thabena fissala (Fieber, 1876) was described from Portugal possibly due to label error (GNezDilov et al. 2011).

Type locality of the species described below, Dalat, is capital of Lam Dong Province situated at about $1500 \mathrm{~m}$ a.s.l. on Langbian Plateau in the southern part of the Central Highlands region of Vietnam.

As reported by the recently published list of Vietnamese Issidae (GNEzDILov et al. 2014a) just one species of the genus, Thabena litaoensis Yang, 1994 is recorded so far from Vietnam, in Hoa Binh Province.

According to our study of type specimens and original descriptions none of the described species of the genus Thabena possesses such peculiar red brownish metope with black glossy spots as the species described below. Typically the metope of other Thabena species is brown or dark brown sometimes with black band below its upper margin (GNEZDilov 2009, fig. 3, CHAN 
et al. 2013, figs 12-15) but never multicoloured. However, morphologically the new species doubtlessly belongs to the genus Thabena. Unfortunately, it is still difficult to give a key to species of the genus as some of them are only known after females.

\section{MATERIAL AND METHODS}

Morphological terminology generally follows Anufriev and Emeljanov (1988) and Gnezdilov et al. (2014b), except Bourgoin et al. (2014) for fore wing venation.

The holotype of the species described below is deposited in the Hungarian Natural History Museum, Budapest, Hungary.

The photos were taken by Leica MZ 95 with camera Leica DFC 290 and then assembled with Helicon Focus 5.3 and Adobe Photoshop CS6. The drawings were made with a Leica MZ95 stereo microscope.

\section{CHECKLIST OF THABENA SPECIES}

\section{Thabena Stål, 1866}

Thabena Stål, 1866a: 208. Type species: Issus retractus Walker, 1857, by subsequent designation (STÅL 1866b: 393).

Cibyra Stål, 1861: 209 (preoccupied). Type species: Issus testudinarius Stål, 1854 (= Issus spectans Walker, 1858), by original designation.

Syn.: Gelastyra Kirkaldy, 1904: 280 (new name for Cibyra Stål, 1861) (Type species: Issus spectans Walker, 1858, syn. of Issus testudinarius Stål, 1854) fide GNEZDilov 2009: 77.

Syn.: Gelastyrella Yang, 1994 in CHAN \& YANG 1994: 90 (Type species: Gelastyrella litaoensis Yang, 1994 in Chan \& Yang 1994) fide Gnezdilov 2009: 77.

Syn.: Borbonissus Bonfils, Attié et Reynaud, 2001: 217 (Type species: Borbonissus brunnifrons Bonfils, Attié et Reynaud, 2001) fide Gnezdilov 2009: 77.

\section{Thabena biplaga (Walker, 1851)}

Issus biplaga Walker, 1851: 367.

Gelastyra biplaga Fennah 1956: 511.

Thabena biplaga GNEZDilov 2009: 79.

Distribution - China (Hong Kong I.) (Walker 1851, Fennah 1956, Gnezdilov 2009).

Note - Described after the female from Hong Kong I. (Walker 1851, Gnezdilov 2009). Habitus is illustrated by FenNAH (1956).

\section{Thabena brunnifrons (Bonfils, Attie et Reynaud, 2001)}

Borbonissus brunnifrons Bonfils, Attie et Reynaud, 2001: 218.

Thabena brunnifrons Gnezdilov 2009: 79. 
Distribution - Reunion I. (France), Rodrigues I. (Republic of Mauritius), Singapore, Taiwan including Dongsha (Pratas) I. (Atтié et al. 2005, 2008, Bonfils et al. 2001, Gnezdilov 2009, Chan et al. 2013).

Note - Described from Reunion Island in Indian Ocean after males and females (BoNFILs et al. 2001). Habitus of adult and 5th instar larva and male genitalia are illustrated (Bonfils et al. 2001, Chan et al. 2013). Host plants are listed, the species is recorded as polyphagous occurring on plants from 22 dicotyledon families (Bonfils et al. 2001, Atтí́ et al. 2005, 2008, Chan et al. 2013).

\section{Thabena decipiens (Melichar, 1906)}

Gelastyra decipiens Melichar, 1906: 264.

Thabena decipiens GnezDILov 2009: 80.

Distribution - Malaysia (Melichar 1906; Gnezdilov 2009).

Note - Described after the female from Perak in Malaysia (Melichar 1906). No illustrations were published.

\section{Thabena diversa (Melichar, 1906)}

Gelastyra diversa Melichar, 1906: 263.

Thabena diversa GNEzDILOv 2009: 80.

Distribution - Myanmar (Melichar 1906; Gnezdilov 2009).

Note - Described after the female from Thagata in Myanmar (Melichar 1906). No illustrations were published.

\section{Thabena fissala (Fieber, 1876)}

Issus fissala Fieber, 1876: 259 [separata 1876: 249].

Thabena fissala Gnezdilov, Soulier-Perkins \& Bourgoin 2011: 29.

Note - Described after a male (or males) from Portugal (FIEBER 1876). Native distribution is unknown. Illustrations published by GNEzDiLov et al. (2011).

\section{Thabena frontocolorata sp. $\mathrm{n}$.}

Distribution - Vietnam.

\section{Thabena lanpingensis Zhang et Chen, 2012}

Thabena lanpingensis Zhang et Chen, 2012: 229.

Distribution - China (Yunnan) (Zhang \& Chen 2012).

Note - Described after males and females, illustrated (Zhang \& CHEN 2012). 


\section{Thabena latifrons (Melichar, 1906)}

Gelastyra latifrons Melichar, 1906: 264.

Thabena latifrons GnezdiLov 2009: 80.

Distribution - Myanmar, Indonesia (Sumatra I., Mentawei Islands, Sipora I.) (MelICHAR 1906).

Note - Described after males and females from Myanmar and Indonesian islands (MELICHAR 1906). The type series have to be examined and the lectotype has to be designated.

\section{Thabena litaoensis (Yang, 1994)}

Gelastyrella litaoensis Yang, 1994: 90 in Chan \& YANG 1994.

Thabena litaoensis GnezdiLov 2009: 80.

Syn: Gelastyrella hainanensis Ran et Liang, 2006: 65, syn. fide Gnezdilov et al. 2014a: 88.

Distribution - China (Hainan I., Fujian, Guangxi) (Ran \& Liang 2006, Zhang \& Chen 2012, Chen et al. 2014), Vietnam (Gnezdilov et al. 2014), Taiwan (Chan \& Yang 1994).

Note - Described after the males and female from Taiwan (CHAN \& YANG 1994). Illustrations published by HorI (1970: as Gelastyra testudinaria), CHAN and YANG (1994), RAN and Liang (2006), Zhang and Chen (2012), and Chan et al. (2013).

\section{Thabena literosa (Walker, 1857)}

Issus literosus Walker, 1857: 154.

Tetrica literosa DisTant 1909: 84.

Thabena literosa GNEzDiLov 2009: 80.

Distribution - Malaysia (Sarawak) (WALKER 1857).

Note - Described after the male from Sarawak (WALKer 1857, comments by GNEZDILOV (2009)). No illustrations are published.

\section{Thabena ovalis (Walker, 1857)}

Issus ovalis Walker, 1857: 154.

Tetrica ovalis Distant 1909: 84.

Thabena ovalis GNEzDILOv 2009: 80.

Distribution - Malaysia (Sarawak, Sabah) (WALKer 1857, GnezdiLov 2009).

Note - Described after the male from Sarawak (WALKER 1857, comments by GNezDilov (2009)). Collected from Cocoa leaves and Malaise trap (GNezdilov 2009). No illustrations are published. 


\section{Thabena retracta (Walker, 1857)}

Issus retractus Walker, 1857: 152.

Thabena retracta STÅL 1866b: 393.

Thabena retracta GNezDiLov 2009: 78.

Distribution - Malaysia (Sarawak, Sabah), Singapore (WALKER 1857, GNezdilov 2009).

Note - Described after the male from Borneo without locality indication (WALKER 1857, comments by GNEzDiLOv (2009)). The holotype and male genitalia of the species after the specimen from Sarawak are illustrated by GNEzDILov (2009).

\section{Thabena testudinaria (Stål, 1854)}

Issus testudinarius Stål, 1854: 246.

Syn: Issus spectans Walker, 1858: 91, syn. fide STÅL 1870: 756.

Gelastyra testudinaria Metcalf 1958: 430.

Thabena testudinaria GNEzDILov 2009: 83.

Distribution - Malaysia (Penang I.) (STÅL 1854).

Note - Described after the female from Pulo Penang (STÅL 1854). No illustrations of type specimen are published. The record of the species from Taiwan (Hori 1970) belongs to T. litaoensis. Records from Indonesia (Java) (WALKer 1858, GNezdilov 2009) and Philippines (STÅL 1870) need verification.

\section{Thabena yunnanensis (Ran et Liang, 2006)}

Gelastyrella yunnanensis Ran et Liang, 2006: 67.

Thabena yunnanensis GNEZDiLov 2009: 83.

Distribution - China (Yunnan) (RAN \& Liang 2006).

Note - Described after male and female, illustrated (RAN \& Liang 2006).

\section{DESCRIPTION OF THE NEW SPECIES}

\section{Thabena frontocolorata sp. $\mathrm{n}$.}

(Figs 1-3, 7, 8)

Type material - Holotype, §ે, Vietnam, Da Lat, “Institute of Biology”, 5.XII.1994, “No. 709", S. Mahunka, Gy. Sziráki \& L. Zombori leg.

Etymology - The species named according to the coloured metope (frons).

Description - Metope wide, glossy, lateral margins convex, upper margin widely concave (Fig. 2). Metope with distinct transverse and median carinae; sublateral carinae may be indicated only after the traces. Metopoclypeal suture relief. Postclypeus large, flattened 
dorso-ventrally, glossy. Ocelli absent. Coryphe transverse, without carina; anterior margin obtusely angulately convex; posterior margin obtusely angulately concave. Fore wings nearly oval, narrowing apically, without hypocostal plate (Figs 1, 7). Caudo-dorsal angle of clavus cuspidal (Fig. 8). ScP+R furcating in proximal half of the wing into ScP+RA and $\mathrm{RP}$; MP 2-branched, furcating near to wing middle; CuA simple; cross veins not numerous. Clavus closed ( $\mathrm{CuP}$ and $\mathrm{Pcu}+\mathrm{A}_{1}$ not running to its cuspidal apex, but running along wing margin) (Figs 7,8$)$. First anal vein $\left(A_{1}\right)$ become the marginal vein. This vein is interrupted
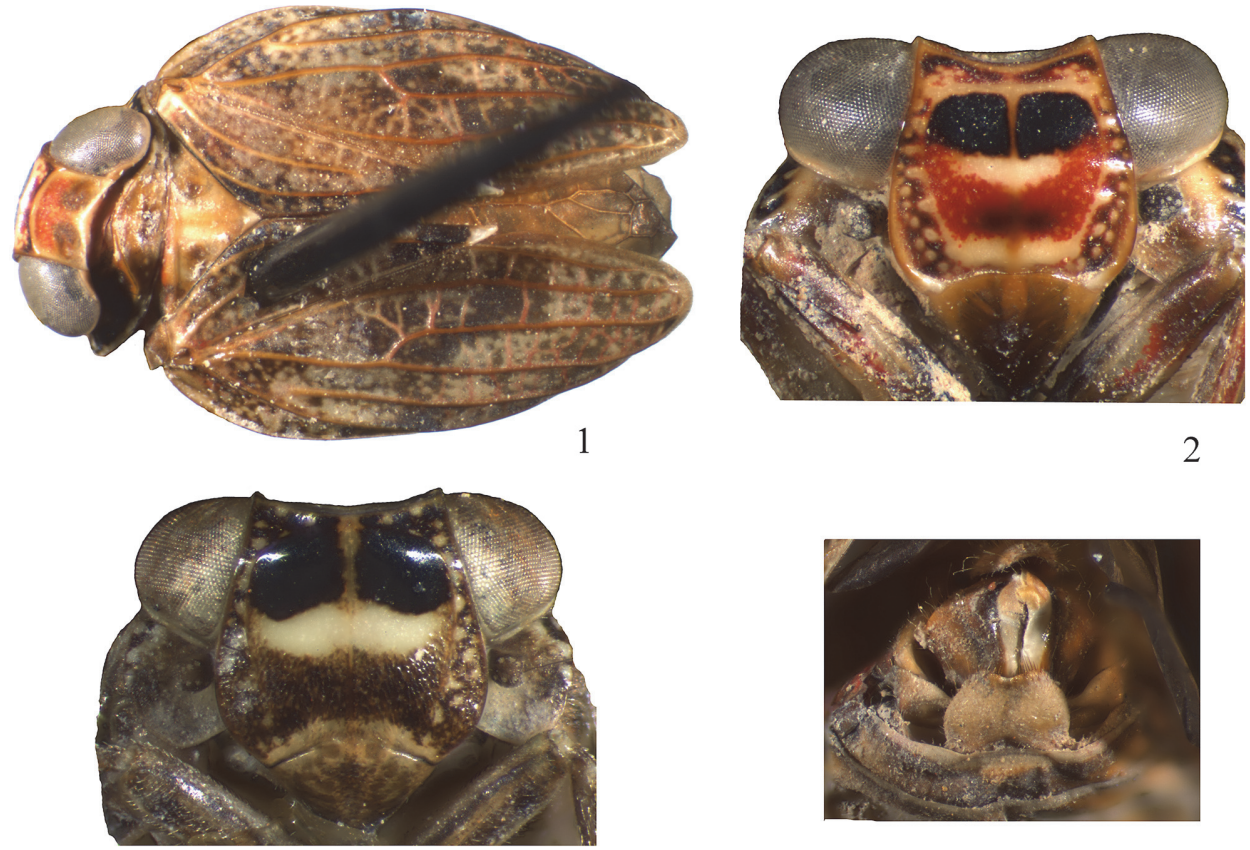

4
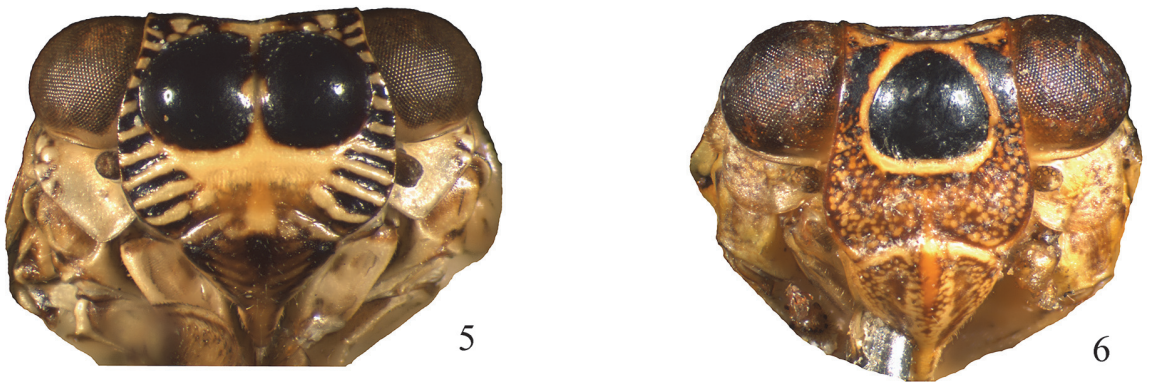

Figs 1-6. Issidae and Caliscelidae. 1-3. Thabena frontocolorata sp. n., holotype, female: $1=$ dorsal view, 2 = frontal view, 3 = ovipositor, ventral view. $4=$ Redarator bimaculatus Distant, 1916 (Issidae), male, frontal view. 5 = Chlamydopteryx mammoides Gnezdilov et Fletcher, 2010 (Issidae), holotype, female, frontal view. 6 = Lasonia kirkaldyi Melichar, 1903 (Caliscelidae), female, frontal view. Total length of T. frontocolorata sp. $\mathrm{n}$. is $5.6 \mathrm{~mm}$. Width of metope: R. bimaculatus: $1 \mathrm{~mm}$; Ch. mammoides: $1.3 \mathrm{~mm}$; L. kirkaldyi: $1.5 \mathrm{~mm}$ 
before the cuspidal apex of clavus (Fig. 8). Hind wings bilobed, with deep cleft between remigium and vannus; costal margin of the wings distinctly concave. Hind tibiae with two lateral spines distally. Apices of tibiae with 7 spines. First metatarsomere a bit longer than second metatarsomere, with two latero-apical spines and 12 intermediate spines arranged in two rows $(6+6)$. Arolium of pretarsus not exceeding the length of claws (in dorsal view).

Colouration - Metope red brownish with light yellow spots (traces of larval sensory pits between lateral margins and traces of sublateral carinae) (Fig. 2). Transverse carina of metope, traces of sublateral carinae, and band above the metopoclypeal suture light yellow. Metope between traces of sublateral carinae red with pair of large glossy black spots below the transverse carina and with light yellow large elongate horizontal spot below the black spots. Genae light yellow with large red spot above the scapus. Scapus, pedicel, and anteclypeus dark brown. Postclypeus brown yellowish. Coryphe light red anteriorly, light yellow brownish posteriorly, with light yellow margins (Fig. 1). Pronotum light brown yellowish with light yellow tubercules - traces of larval sensory pits. Mesonotum light yellow brownish with pair of light brown spots laterally. Paranotal lobes of pronotum with black margins and light yellow transverse stripes. Epimera of mesonotum black below the wings, light yellow medially and dark brown basally. Fore wings light brown with dark brown patches, veins light brown or reddish. Cuspidal apex of clavus white. Hind wings brown. Abdomi-
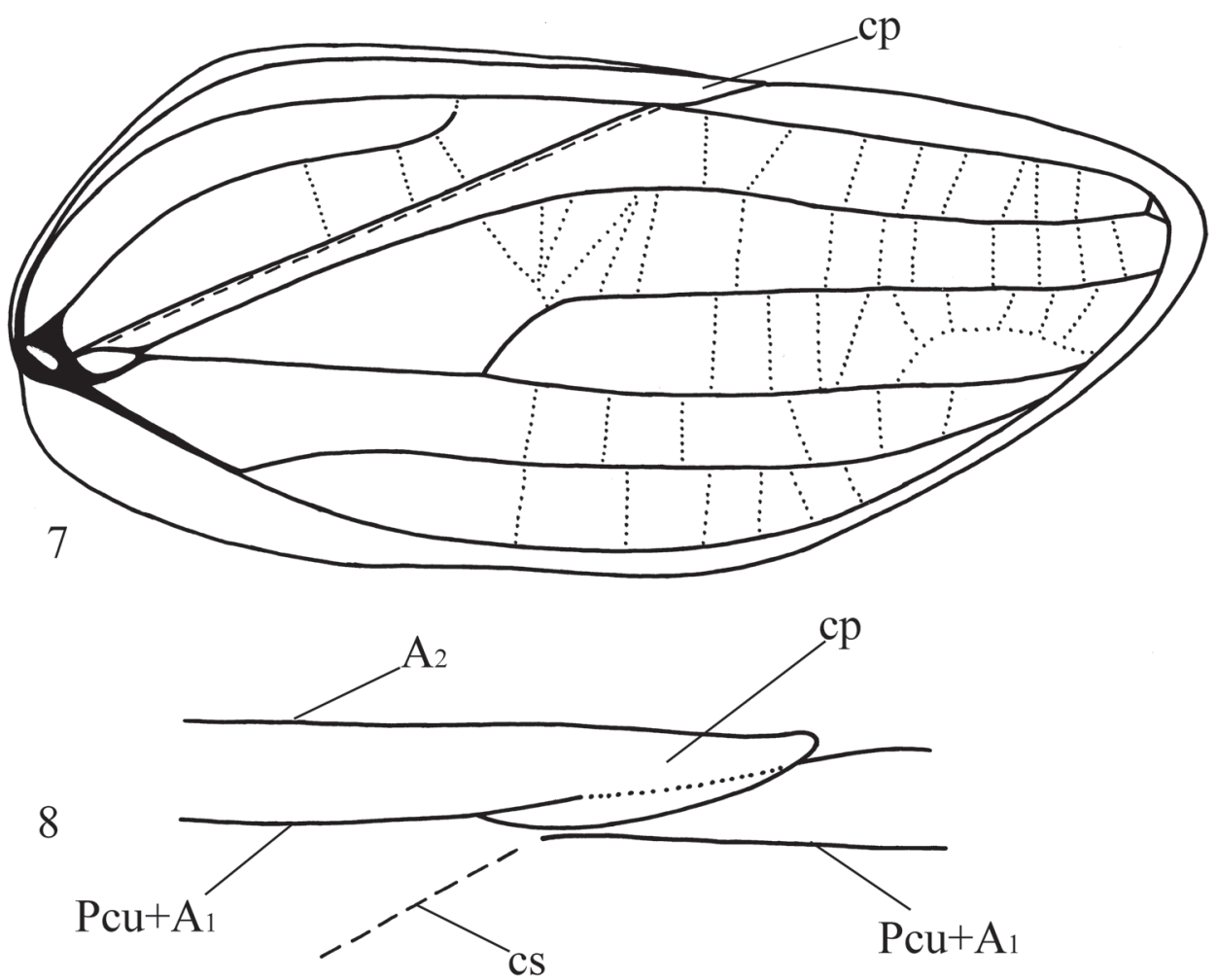

Figs 7-8. Thabena frontocolorata sp. n., holotype, female: 7 = fore wing, $8=$ forewing, apex of clavus. Abbreviations: $\mathrm{cp}$ - cuspidal apex of clavus; $\mathrm{cs}$ - claval suture; Pcu - postcubital vein; $A_{1}$ - first anal vein; $A_{2}$ - second anal vein. Total length of T. frontocolorata sp. $n$. is $5.6 \mathrm{~mm}$ 
nal tergites brown reddish. Abdominal sternites light yellow brownish. Femora and tibiae yellow brownish with dark brown spots and longitudinal red stripes particularly on tibiae. Apices of 3rd tarsomeres and claws dark brown. Apices of spines black. Gonoplacs dark brown yellowish with light yellow margins (Fig. 3). Anal tube light yellow.

Female genitalia - Hind margin of sternum VII with large median process (Fig. 3). The process wide with convex lateral margins, concave apically. Anal tube at least 3 times as wide as long. Anal column short. Gonoplacs without carinae.

Total length $-5.6 \mathrm{~mm}$.

\section{DISCUSSION}

The metope with glossy spots described above for T. frontocolorata sp. n. is also the character of the south Indian genus Redarator Distant, 1916 (Fig. 4) from the tribe Issini. However, Redarator differs from Thabena by absence of transverse carina on metope, presence of well visible sublateral carinae, slightly narrowing apically fore wings with 2-branched $\mathrm{CuA}$, hind wings 3-lobed, hind margin of female sternum VII without large median process, and anal tube of male and female long and narrow. Apparently, such structure of metope of these two genera is a kind of mimicry of the large frontal eyes of salticid spiders as was expected for another Issini species, the Australian Chlamydopteryx mammoides Gnezdilov et Fletcher, 2010 (Fig. 5) (GNezDilov \& FLETCHER 2010) and for an Eurybrachyidae species, the Australian Gelastopsis insignis Kirkaldy, 1906 (Constant 2005). Another condition of the "metopial eye" but apparently with the same function is a character of Lasonia kirkaldyi Melichar, 1903 (Fig. 6) - endemic Sri Lankan Caliscelidae.

According to the venation of fore wings with 2-branched radius ( $\mathrm{ScP}+\mathrm{RA}$, $\mathrm{RP})$ and median (MP1, MP2) and simple cubitus anterior (CuA) and the presence of clavus with peculiar cuspidal caudo-dorsal angle (cuspidal apex) (Fig. 8), well developed bilobed hind wings with deep cleft between remigium and vannus and rudimentary anal lobe, and large median process of hind margin of female sternum VII (Fig. 3) the genus Thabena is closely related to the genus Pseudochoutagus Che, Zhang et Wang, 2011 (Che et al. 2011; Gnezdilov \& ConSTANT 2012). The last genus is known from Northern Vietnam and Hainan I. (China) with two species.

Apparently, Thabena as well as Pseudochoutagus may be treated as close to the ancestor of the tribe Parahiraciini Cheng et Yang or even as the members of this tribe according to the structure of hind wings mentioned above which is one of the apomorphies of the tribe (GNezDILOv \& WILSON 2007). This point of view is confirmed also by the molecular data where Thabena is placed in one cluster with "typical" Parahiraciini (Sun et al. 2015). For final solution of this question a thorough phylogenetic analysis of the family Issidae is necessary. 
Acknowledgements - I am sincerely grateful to Mr. András Orosz (Budapest, Hungary) for his hospitality in the Hungarian Natural History Museum and kind help, Dr. Mária Tóth (Budapest, Hungary) and Dr. Gunvi Lindberg (Stockholm, Sweden) for checking type specimens, Mr. Mick Webb (London, UK) for his permission to study Redarator bimaculatus Distant specimens, and Prof. Dr. Masami Hayashi (Saitama, Japan) for his help with literature. My trip and research study in Budapest were financially supported by the Hungarian Academy of Sciences (Budapest) and the Alexander von Humboldt Stiftung (Bonn, Germany) and performed in the frames of the Russian state research project no. 01201351189.

\section{REFERENCES}

Anufriev, G. A. \& Emeljanov, A. F. (1988) Suborder Cicadinea (Auchenorrhyncha). Pp. 12-495. In: Ler, P. A. (ed.): Opredelitel' nasekomykh Dal'nego Vostoka SSSR, 2 [Keys to the insects of the Far East of the USSR. Volume 2. Homoptera and Heteroptera]. Nauka, Leningrad.

Attié, M., Baret, S. \& Strasberg, D. (2005) Les insectes phytophages associés à des plantes exotiques envahissantes à l'île de La Réunion (Mascareignes). Revue D'Ecologie - la Terre et la Vie 60: 107-125.

Attié, M., Bourgoin, T., Veslot, J. \& Soulier-Perkins, A. (2008) Patterns of trophic relationships between planthoppers (Hemiptera: Fulgoromorpha) and their host plants on the Mascarene Islands. Journal of Natural History 42(2-3): 1591-1638. doi: org $/ 10.1080 / 00222930802106963$

Bonfils, J., Attié, M. \& Reynaud, B. (2001) Un nouveau genre d'Issidae de l'île de la Réunion: Borbonissus n. gen. (Hemiptera, Fulgoromorpha). Bulletin de la Société Entomologique de France 106: 217-224.

Bourgoin, T. (2015) FLOW (Fulgoromorpha Lists on The Web): a world knowledge base dedicated to Fulgoromorpha. Updated at: http://hemiptera-databases.org/flow/ [accessed July 22, 2015]

Bourgoin, T., Wang, R. R., Asche, M., Нoch, H., Soulier-Perkins, A., Stroiński, A., YAP, S. \& Szwedo, J. (2014) From micropterism to hyperpterism: recognition strategy and standardized homology-driven terminology of the forewing venation patterns in planthoppers (Hemiptera: Fulgoromorpha). Zoomorphology 134: 63-77. doi: org/10.1007/s00435-014-0243-6

Chan, Mei-Ling \& Yang, Chung-Tu (1994) Issidae of Taiwan (Homoptera: Fulgoroidea). Chen Chung Book, Taichung, 188 pp.

Chan, Mei-Ling, Yeh, Hsin-Ting \& Gnezdilov, V. M. (2013) Thabena brunnifrons (Hemiptera: Issidae), new alien species in Taiwan, with notes on its biology and nymphal morphology. Formosan Entomologist 33: 149-159.

Che, Yanli, Zhang, Yalin \& Wang, Yinglun (2011) A new genus of the tribe Issini Spinola (Hemiptera: Fulgoroidea: Issidae) from China. Zootaxa 3060: 62-66.

Chen, Xiang-Sheng, Zhang, Zheng-Guang \& Chang, Zhi-Min (2014) Issidae and Caliscelidae (Hemiptera: Fulgoroidea) from China. Guizhou Science and Technology Publishing House, Guiyang, 242 pp. 
Constant, J. (2005) Revision of the Eurybrachidae (IV). The Australian genus Gelastopsis Kirkaldy, 1906 (Hemiptera: Fulgoromorpha: Eurybrachidae). Bulletin de l'Institut Royal des Sciences Naturelles de Belgique, Entomologie 75: 57-69.

Distant, W. L. (1909) Rhynchotal Notes XLVIII. Annals \& Magazine of Natural History (ser. 8) 4: 73-87.

Fieber, F.-X. (1876) Les Cicadines d'Europe d'après les originaux et les publications les plus récentes. Deuxième partie: Descriptions des espèces. Traduit de l'Allemand par Ferd. Rieber [sic]. Revue et Magasin de Zoologie, Ser. 3 4: 11-268.

Gnezdilov, V. M. (2009) Revisionary notes on some tropical Issidae and Nogodinidae (Hemiptera: Fulgoroidea). Acta Entomologica Musei Nationalis Pragae 49(1): 75-92.

Gnezdilov, V. M. (2013) Modern classification and the distribution of the family Issidae Spinola (Homoptera, Auchenorrhyncha, Fulgoroidea). Entomologicheskoe obozrenie 92(4): 724-738. [English translation published in Entomological Review, 2014, 94(5): 687-697. doi: 10.1134/S0013873814050054]

Gnezdilov, V. M. \& Wilson, M. R. (2007) Review of the genus Scantinius Stål with notes on the tribe Parahiraciini Cheng \& Yang (Hemiptera: Auchenorrhyncha: Fulgoroidea: Issidae). Arthropod Systematics \& Phylogeny 65(1): 101-108.

Gnezdilov, V. M. \& Constant, J. (2012) Review of the family Issidae (Hemiptera: Fulgoromorpha) in Vietnam with description of a new species. Annales Zoologici, Warszawa 62(4): 571-576. doi: 10.3161/000345412X659632

Gnezdilov, V. M. \& Fletcher, M. J. (2010) A review of the Australian genera of the planthopper family Issidae (Hemiptera: Fulgoromorpha) with description of an unusual new species of Chlamydopteryx Kirkaldy. Zootaxa 2366: 35-45.

Gnezdilov, V. M., Soulier-Perkins, A. \& Bourgoin, T. (2011) Fieber's original drawings and their corresponding types for the family Issidae (Hemiptera, Fulgoromorpha) in the Muséum national d'Histoire naturelle of Paris, France. Zootaxa 2806: 24-34.

Gnezdilov, V. M., Bourgoin, T. \& Soulier-Perkins, A. (2014a) Vietnamese Issidae (Hemiptera, Fulgoroidea): new taxa, new records and new distribution data. Zootaxa 3847(1): 80-96. doi: 10.11646/zootaxa.3847.1.4

Gnezdilov, V. M., Holzinger, W. E. \& Wilson, M. R. (2014b) The Western Palaearctic Issidae (Hemiptera, Fulgoroidea): an illustrated checklist and key to genera and subgenera. Proceedings of the Zoological Institute RAS, Vol. 318, Supplement 1, $124 \mathrm{pp}$.

Hori, Y. (1970) A species of Gelastyra new to Taiwan (Hemiptera: Issidae). Ageha 4(11): 8.

Kirkaldy, G. W. (1904) Bibliographical and nomenclatorial notes on the Hemiptera. 3. Entomologist, London 37: 279-283.

Melichar, L. (1906) Monographie der Issiden (Homoptera). Abhandlungen der KaiserlichKöniglichen Zoologisch-Botanischen Gesellschaft in Wien 3: 1-327.

Metcalf, Z. P. (1958) Fulgoroidea. Issidae. General catalogue of the Homoptera. Fasc. 4., Pt. 15. Waverly Press, Baltimore, 561 pp.

Ran, Hong-Fan \& Liang, Ai-PIng (2006) The issid genus Gelastyrella Yang (Hemiptera: Fulgoroidea: Issidae) from China. Zootaxa 1238: 63-68.

STÅL, C. (1854) Nya Hemiptera. Öfversigt af Kongliga Vetenskaps-Akademiens Förhandlingar 11: $231-255$.

STÅL, C. (1861) Nova methodus familias quasdam Hemipterorum disponendi. Öfversigt af Kongliga Svenska Vetenskaps-Akademiens Förhandlingar 18: 195-223.

STÅL, C. (1866a) Hemiptera Homoptera Latr. Hemiptera Africana 4: 1-276.

STÅL, C. (1866b) Analecta Hemipterologica. Berliner Entomologische Zeitschrift 10: 381-394. doi: $10.1002 / \mathrm{mmnd} .18660100410$ 
STÅL, C. (1870) Hemiptera insularum Philippinarum. - Bidrag till Philippinska öarnes Hemipter-fauna. Öfversigt af Kongliga Svenska Vetenskaps-Akademiens Förhandlingar 27: 607-776.

Sun, Yanchun, Meng, Rui \& Wang, Yinglun (2015) Molecular systematics of the Issidae (Hemiptera: Fulgoroidea) from China based on wingless and 18S rDNA sequence data. Entomotaxonomia 37(1): 15-26.

WALKER, F. (1851) List of the specimens of homopterous insects in the collection of the British Museum 2: 261-636 + plates 3-4.

WALKER, F. (1858) List of the specimens of homopterous insects in the collection of the British Museum. Supplement. E. Newman, London. 369 pp.

Zhang, Zheng-Guang \& Chen, XIANG-Sheng (2012) A review of the genus Thabena Stål (Hemiptera: Fulgoromorpha: Issidae) from China with description of one new species. Entomotaxonomia 34(2): 227-232.

Revised version received December 12, 2014, accepted July 28, 2015, published October 19, 2015 